\title{
Holstein-Friesian Dairy Cows Under a Predominantly Grazing System: Interaction Between Genotype and Environment
}

\author{
W. J. Fulkerson, ${ }^{\star 1}$ T. M. Davison,† S. C. Garcia, ${ }^{\star}$ G. Hough, $¥$ M. E. Goddard,§ R. Dobos,\# and M. Blockey $\|$ \\ *University of Sydney, Private Bag 3, Camden, New South Wales, 2570, Australia \\ t94 Durham Rd, Surrey Hills, Victoria, 3127, Australia \\ ‡Glenys Hough Consulting, PO Box 7011, Eaton, Western Australia, 6232, Australia \\ §University of Melbourne, Parkville, Victoria, 3052, Australia \\ \#NSW DPI, Armidale, 2350, Australia \\ ||Scotts Head, New South Wales, 2447, Australia
}

\section{ABSTRACT}

A 5 yr whole-system study, beginning in June 1994, compared the productivity of high [HGM; Australian Breeding Value (ABV) of $49.1 \mathrm{~kg}$ of fat plus protein] and low [LGM; ABV of $2.3 \mathrm{~kg}$ of fat plus protein] genetic merit cows. Cows from both groups were fed at 3 levels of concentrate $(\mathrm{C}): 0.34$ (low $\mathrm{C}$ ), 0.84 (medium $\mathrm{C}$ ), and 1.71 (high C) $t$ of $\mathrm{DM} /$ cow per lactation. Thus, there were 6 treatments (farmlets) composed of 18 cows each. The 30 blocks of pasture on each farmlet were matched between farmlets for pasture growth before the study (and soil characteristics and aspect). Cows were culled, and pasture and feed use were managed so as not to bias any one treatment. Genetic merit, level of feeding, and their interaction were significant effects for protein content, protein/cow, and milk and protein/ha. For fat and milk yield/cow, genetic merit and level of feeding were significant, whereas there was no significant effect of genetic merit on fat content. The difference of 46.8 $\mathrm{kg}$ of fat plus protein yield between the ABV of HGM and LGM cows and the actual difference in production between the 2 groups was not significantly different except for low $\mathrm{C}(27 \mathrm{~kg})$ cows. This was due to a 3 -fold lower protein yield difference ( $6 \mathrm{~kg} / \mathrm{cow})$ compared with an ABV difference for protein yield of $17.9 \mathrm{~kg} / \mathrm{cow}$. The dramatic effect of treatment on protein is in line with differences in the mean protein content $(2.89 \%$ for the HGM - low C cows compared with a mean of $3.02 \%$ for the remaining groups) and mean body condition score [4.3 for HGM - low C cows compared with 4.8 for the mean of the remaining groups (scale 1 to 8)], both indicators reflecting a higher negative energy balance in the HGM - low C cows. When individual cow production was plotted against ABV for production of milk or pro-

Received February 25, 2007.

Accepted November 2, 2007.

${ }^{1}$ Corresponding author: billf@camden.usyd.edu.au tein yield all relationships were quadratic, but the slope was relatively flat (low response to $\mathrm{ABV}$ ) for the low $\mathrm{C}$ cows, steeper for the medium $\mathrm{C}$ cows and steepest (but not linear) for the high $\mathrm{C}$ cows. The relationship between ABV for fat yield and actual fat yield was linear for all levels of concentrate. The mean milk yield/ha from pasture for the 6 farmlets over the $5 \mathrm{yr}$ was 11,868 $\mathrm{L}, 11,417 \mathrm{~L}$, or $7,761 \mathrm{~L}$ for the HGM cows fed at low C, medium C, or high C, respectively, and 10,579 L, 9,800 $\mathrm{L}$, or 5,812 L for LGM cows, fed at low C, medium C, or high $\mathrm{C}$, respectively. The response to concentrates fed was very high for the HGM - medium C cows at $0.115 \mathrm{~kg}$ fat plus protein or $1.75 \mathrm{~L}$ milk/kg of concentrate fed, with comparable figures of $0.083 \mathrm{~kg}$ and $1.0 \mathrm{~L}, 0.86$ $\mathrm{kg}$ and $1.47 \mathrm{~L}$ and 0.066 and $0.92 \mathrm{~L} / \mathrm{kg}$ of concentrate fed for the HGM - high C, LGM - medium C, and LGM - high C, respectively. The results show a significant genetic merit by environment (level of feeding) interaction for reproduction and most production parameters when considered in terms of the individual cow and the whole farm system.

Key words: dairy cow, genetic merit, feeding, genetic merit $\times$ feeding interaction

\section{INTRODUCTION}

Over the last $50 \mathrm{yr}$, milk production of dairy cows has increased substantially worldwide. For example, in the United States, milk production has risen from an average of $3,173 \mathrm{~kg} / \mathrm{cow}$ in $1958-1962$ to $8,879 \mathrm{~kg} / \mathrm{cow}$ in 2005 (USDA, 1964, 2006). Likewise, in the United Kingdom, milk production rose from $3,000 \mathrm{~kg} / \mathrm{cow}$ in 1951 to $4,500 \mathrm{~kg} / \mathrm{cow}$ in 1973 (Foote, 1978) to $6,500 \mathrm{~kg} /$ cow at present (Colman et al., 2004). The increase in milk production in Australia has been just as impressive, increasing from $2,889 \mathrm{~kg} / \mathrm{cow}$ in 1980 to $5,037 \mathrm{~kg} /$ cow in 2005 (Dairy Outlook, 2006).

In Australia, a number of reasons for this increase in production/cow can be identified. First, there has been a marked shift in breed popularity from Jersey to 
Holstein-Friesian, which now constitutes $80 \%$ of the national herd (Fulkerson and Doyle, 2001). Second, importation of North American Holstein genetics combined with an effective Australian breeding program using BLUP to calculate estimated breeding values has resulted in genetic improvement in milk production in the last few decades. Third, the amount of (high energy dense) concentrates fed to dairy cows has increased substantially. For example, in the major dairy state of Victoria, concentrates fed has increased from near zero in the early $1980 \mathrm{~s}$ to over $1.5 \mathrm{t} / \mathrm{cow}$ per yr in 2002 (Fulkerson and Doyle, 2001). A major reason for this has been attempts to exploit the increased genetic merit, recognizing in theory that even the best quality pasture can only provide sufficient ME for about $27 \mathrm{~L}$ of milk/cow per d (van Vuuren, 1993) due to intake constraints, and in practice this is probably closer to 20 to $22 \mathrm{~L}$ of milk/cow per d.

Although genetic change has increased milk production, this has resulted in other less desirable consequences.

First, fat and protein content of milk has fallen due to the negative relationships between milk yield and component concentrations (Keller and Allaire, 1989).

Second, Grainger et al. (1985) found that although cows of high genetic merit on a predominantly grazed pasture diet produced more milk, this was due to their willingness to partition more nutrients to milk production. Where nutrient intake is inadequate (as in the pasture-based systems in Australia with seasonal fluctuations in pasture growth and due to the high cost of supplements, or both) cows must increasingly mobilize body reserves (Holmes and MacMillan, 1982). If mobilization of body reserves becomes excessive, poor reproductive performance results (Harrison et al., 1990; Bonczeb et al., 1992).

Third, and probably most importantly, herd fertility has declined. Unfortunately, there are no national surveys over time in Australia on dairy herd fertility, but there are some regional surveys which can be compared with the recent national In Calf (Morton, 2003) survey. Fulkerson and Dickens (1985) conducted a survey of 30 herds composed of 2,593 cows. The estimated pregnancy rate (nonreturn to service rates adjusted for submission rate) after 1 cycle of mating was $68 \%$ for the spring calving herds. Judd et al. (1990) surveyed 2,050 cows from 50 seasonally calving commercial herds in the Macallister region of South Eastern Victoria and found a pregnancy rate of $59 \%$ after 2 inseminations. In the In Calf survey (Morton, 2003), the estimated 6-wk pregnancy rate for seasonally calving herds in Australia is currently 50\%. Thus, pregnancy rates have fallen by about $1 \%$ per year. Therefore, the situation in Australia is probably similar to that in other countries where the decline in fertility of dairy cows has been well documented, particularly since 1975 (see Rauw et al., 1998; Dillon et al., 2006).

Fourth, there has been a move away from a low cost seasonal block calving system of farming as a response to poor reproductive performance, where cow requirements closely match pasture availability, and toward split calving or even all-year-round calving. For example, in Victoria, over 50\% of farmers now supply some milk in each month of the year. This, together with the increased use of concentrates has increased the cost of production. In the last decade, feed costs, as a percentage of total costs, have increased from 17 to 28\% (Dairy Outlook, 2006).

Fifth, improvement in (milk) production in Australian dairy cows has been synonymous with the inflow of North American genes, which was over $60 \%$ in 2000 and is now over $80 \%$.

In response to this, some farmers have begun to question whether the industry has been moving in the most appropriate direction. Is the best genotype for a lowcost production system, which relies on good fertility to achieve seasonal calving, different than the best genotype for a production system with a higher level of concentrate feeding? To answer this question, this experiment commenced in 1994 to study the effect of interaction between genotype and feeding level on milk production and fertility of Holstein-Friesian cows at both the whole system and the individual cow levels. If the interaction is not significant, then we can continue to rely on sires selected in the North American environment. If the interaction is significant, we need to change our herd improvement goals or accept that feeding practices and management will need to continue to change to accommodate this changing genotype.

Research on the interaction between genotype and environment also commenced at Langhill in Scotland (Veerkamp et al., 1995) and Moorepark in Ireland (Buckley et al., 2000) at about the same time as the present study. The present study differs from these studies in that a greater range of feeding levels were considered and it was predominantly a grazing situation. Also, the differences in genetic merit were far greater in this study, but reflect the variations found in the Australian Dairy industry in 1994. An important feature of the experimental design is that high genetic merit (HGM) and low genetic merit (LGM) cows were run as separate herds, so that the HGM cows had only the same average feed available as the LGM cows.

The results on the reproductive performance of cows in this study have been published previously by Fulkerson et al. (2001). Briefly, HGM cows had poorer reproductive performance than LGM cows (70 and $87 \%$ pregnancy rate, respectively, after 12 wk of mating). 
Table 1. Mean \pm SE\% North American ancestry for all animals used over the 5-yr period of the study, and the Australian breeding values for milk, fat and protein yield at the commencement of the study ${ }^{1}$

\begin{tabular}{|c|c|c|c|c|c|c|}
\hline \multirow[b]{2}{*}{ Item } & \multicolumn{3}{|c|}{ High genetic merit } & \multicolumn{3}{|c|}{ Low genetic merit } \\
\hline & Low $\mathrm{C}$ & Medium C & High C & Low C & Medium C & High C \\
\hline $\begin{array}{l}\% \text { North American genes } \\
\text { Australian breeding value for }\end{array}$ & $59 \pm 6$ & $61 \pm 7$ & $63 \pm 7$ & $17 \pm 3$ & $28 \pm 2$ & $20 \pm 4$ \\
\hline Fat yield (kg) & 29 & 31 & 31 & 4 & 5 & 0 \\
\hline Protein yield (kg) & 18 & 18 & 16 & 6 & 2 & 2 \\
\hline Milk yield (L) & 728 & 659 & 682 & -1 & -22 & -62 \\
\hline
\end{tabular}

${ }^{1}$ Low, medium, and high concentrate $(\mathrm{C}): 0.34,0.84$, and $1.71 \mathrm{t}$ of $\mathrm{DM} / \mathrm{cow}$ per lactation, respectively.

\section{MATERIALS AND METHODS}

The study was undertaken over a 5-yr period from June 1994 to October 1999 at Wollongbar Agricultural Institute, New South Wales, Australia (located $20 \mathrm{~km}$ from the east coast; elevation $160 \mathrm{~m}$; latitude $28^{\circ} \mathrm{S}$; longitude $\left.153^{\circ} \mathrm{E}\right)$. The climate is subtropical with longterm annual rainfall of $1,613 \mathrm{~mm}$, highest mean monthly maximum temperature in February of $27.5^{\circ} \mathrm{C}$, and lowest mean monthly minimum temperature in July of $10^{\circ} \mathrm{C}$. The use of the animals in these experiments was approved by the Animal Ethics Committee of the New South Wales Department of Primary Industries.

\section{Experimental Design}

Three HGM and 3 LGM herds of 18 cows each were allocated to 1 of 6 closed matched farmlets in a complete randomized design. The percentage of North American genes and average Australian breeding values (ABV) for production (1990 base year) for cows in each herd at the time each animal entered the farmlet are shown in Table 1. It is common in Australia to express ABV values as the sum of $A B V$ for fat yield and $A B V$ for protein yield because milk is commercialized based on fat and protein content in the main dairy states (e.g., Victoria).

\section{Origin of Cows}

The LGM cows originated from the Guernsey breed, artificially inseminated using semen from HolsteinFriesian proven sires (based on fat yield) from 1965 to 1985. From 1985 until the end of the study in 1999, the cows were inseminated using semen from HolsteinFriesian sires with a zero ABV for fat yield.

The HGM cows were purchased from commercial dairy farmers from dams with the highest ABV (fat yield) available throughout Australia in 1984/1985. The animals were then bred to proven sires (Genetics Australia, Melbourne, Victoria) with the highest available $\mathrm{ABV}$ (fat yield) but with $\mathrm{ABV}$ values for functional traits (overall udder, overall feet and legs, milking temperament) of zero or better. Each year, 2 different bulls were used to minimize inbreeding. The LGM cows represented the genetic merit of the national herd in the pre1980 s, and HGM cows represented the highest genetic merit available at that time.

\section{The Farmlets}

Each farmlet comprised 6 ha of pasture with approximately 0.66 of the area as kikuyu (Pennisetum clandestinum)-based pasture, oversown in autumn with short rotation ryegrass (Lolium multiflorum), and one-third area sown with perennial ryegrass (Lolium perenne). The proportion of each pasture type was typical of dairy farms in the region. The effective stocking rate (milkers plus dry cows) was 3.3 cows/ha.

The 30 blocks within each farmlet were matched between farmlets for soil characteristics, as well as the pasture grown and utilized in the previous 9 mo before the study commenced. The soil type was uniform over all farmlets and was a well drained red Krasnozem soil of Basaltic origin (classification Ug; Northcote, 1974).

\section{Allocation of Cows to Farmlets}

Within genetic merit (HGM vs. LGM, respectively), cows were allocated to their feeding level treatment groups based on similar ABV for fat/cow (31 vs. $3 \mathrm{~kg}$ ), milk yield in previous lactation $(5,666$ vs. $5,113 \mathrm{~L} / \mathrm{cow}$ per lactation) and at the commencement of the study (18.2 vs. $15.3 \mathrm{~L} / \mathrm{cow}$ per day), live weight (534 vs. 519 $\mathrm{kg})$, and age (5.0 vs. $5.3 \mathrm{yr})$.

\section{Level of Concentrate Fed}

The average amount of concentrate $(\mathbf{C})$ fed over the 5 -yr period for each feeding level group was 1) Low C: $0.34 \mathrm{t}$ of $\mathrm{DM} /$ cow per lactation fed from December to March to correct for low ME (mean of $8.9 \mathrm{MJ} / \mathrm{kg}$ of DM) and low sodium, calcium, phosphorous, and magnesium contents of kikuyu grass pasture; 2) Medium C: $0.84 \mathrm{t}$ of $\mathrm{DM} /$ cow per lactation, which was about the industry 
standard in 1992 (Kellaway and Harrington, 2004); and 3) High C: $1.71 \mathrm{t}$ of DM/cow per lactation, equal to the maximum fed at the time the study commenced.

The concentrate was fed twice daily at milking in all cases. The daily amount of concentrates fed to the high $\mathrm{C}$ groups was always twice that fed to the medium $\mathrm{C}$ groups. The actual nutrient specifications of the diet were formulated to satisfy the HGM-high C group and were based on the Cornell Net Carbohydrate and Protein System Ration Formulation model. This gave a factorial combination of treatments with 2 levels of genetic merit and 3 levels of feeding.

\section{Pasture Intake}

The pasture intake/cow for each group of cows was predicted from the $\mathrm{ME}$ requirements for production, maintenance and liveweight change according to the relationships in SCA (1990), and the known ME values of the feeds offered to each herd.

The changes in liveweight were based on 3-wk rolling averages with $1 \mathrm{~kg}$ of live weight gain assumed to require $34 \mathrm{MJ}$ of $\mathrm{ME}$ and the loss of $1 \mathrm{~kg}$ of live weight liberating $28 \mathrm{MJ}$ of ME (SCA,1990).

The predicted net energy required for milk production was based on its fat, protein, and lactose content according to the relationship:

$$
\begin{aligned}
& \text { Net energy }(\mathrm{MJ} / \mathrm{L} \text { of milk })=0.0381 \mathrm{fat} \\
& \quad+0.0245 \text { protein }+0.0165 \text { lactose }
\end{aligned}
$$

with milk components expressed in grams per liter of milk.

The ME requirements were then calculated assuming an efficiency of utilization of $62 \%$ for all groups because this is not affected by genotype (Yan et al., 2006).

The estimated ME values for the feeds consumed was based on OM digestibility (OMD) values as described in SCA (1990):

$$
\begin{gathered}
\text { Metabolizable energy }(\mathrm{MJ} / \mathrm{kg} \mathrm{DM})=\mathrm{OMD}(\%) \\
\times 0.16-1.8
\end{gathered}
$$

Pasture utilized (kg of DM/ha) was calculated for 2 periods in each of the $5 \mathrm{yr}$ : period 1, from May 1 to November 30 , defined as predominantly ryegrass; and period 2, from December 1 to April 30, predominantly kikuyu.

Pasture samples for analysis of OMD, CP, NDF, and minerals were taken by plucking herbage to estimated grazing height at weekly intervals in 1994/1995 and at monthly intervals after that (see Fulkerson et al., 1998). The nutrient analyses were then used to formulate ra- tions on a weekly basis and to calculate pasture intake and pasture utilized as outlined above.

\section{Culling and Replacements}

The cows had a mean age of $5.2 \mathrm{yr}$ at the commencement of the study, and the replacement rate was $22 \%$, reflecting the industry standard. The criterion for culling was based on the need to retain a comparable age structure within each herd. The primary criterion for culling was pregnancy status.

If less than 4 cows/herd per yr were not pregnant, the extra cows needed to bring the number culled to 4 would be chosen in a way that ensured equal status (age, ABV and production). If more than 4 cows/herd per yr were not pregnant (very seldom), the additional cows would be replaced by cows of similar status (outlined above). If cows were culled during lactation (based on objective veterinary assessment), they were replaced by cows of similar status.

Although these practices ensured the age structure remained similar between herds, it diminished the influence of reproductive performance on productivity. In a commercial herd, lower culling rates due to high reproductive performance would permit increased culling for low production or allow cows to be retained longer in the herd, both of which would increase production/cow.

\section{Grazing Management}

The best practice of pasture management for ryegrass was based on the studies by Fulkerson and Donaghy (2001) and for kikuyu on the studies by Reeves et al. (1996). It was critical that grazing management was based on objective criteria, which would allow a valid comparison to be made between farmlets and herds. On each farmlet, 0.66 ha of the total 6 ha was sown to maize (Zea mays) each year and conserved as silage to be used as the main "buffer" feed to address seasonal shortages in pasture availability and to provide the flexibility to apply appropriate grazing management criteria.

\section{Performance Recording}

Milk yield was recorded by flow meters at weekly intervals from a pooled a.m./p.m. milk sample which was analyzed for fat and protein using infrared milk analysis (MilkoScan FT120, Foss Electric, Hillerød, Denmark). Body condition was scored (scale 1 to 8; Earle, 1976) at 3 monthly intervals. 
Table 2. Milk (L), fat content (\%), and yield (kg), protein content (\%), and yield (kg) per cow per lactation and protein and fat yield (kg/ha) averaged over the $5 \mathrm{yr}$ of the study (values are for completed lactations only)

\begin{tabular}{|c|c|c|c|c|c|c|c|c|c|}
\hline \multirow[b]{2}{*}{ Item } & \multicolumn{3}{|c|}{ High genetic merit } & \multicolumn{3}{|c|}{ Low genetic merit } & \multicolumn{3}{|c|}{$\operatorname{Effect}^{1}(P=)$} \\
\hline & $\mathrm{LC}$ & $\mathrm{MC}$ & $\mathrm{HC}$ & $\mathrm{LC}$ & MC & $\mathrm{HC}$ & GM & $\mathrm{C}$ & $\mathrm{GM} \times \mathrm{C}$ \\
\hline Milk (L/cow) & 4,951 & 5,779 & 6,451 & 4,508 & 5,241 & 5,776 & $<0.001$ & $<0.001$ & 0.44 \\
\hline Protein $(\%)$ & 2.89 & 2.96 & 3.02 & 3.04 & 2.97 & 3.08 & $<0.001$ & 0.002 & 0.01 \\
\hline Fat $(\%)$ & 3.85 & 3.87 & 3.88 & 3.73 & 3.76 & 3.71 & 0.003 & 0.88 & 0.76 \\
\hline Protein (kg/cow) & 143 & 174 & 195 & 137 & 157 & 178 & $<0.001$ & $<0.001$ & 0.04 \\
\hline Fat $(\mathrm{kg} / \mathrm{cow})$ & 188 & 220 & 244 & 166 & 196 & 212 & $<0.001$ & $<0.001$ & 0.37 \\
\hline Protein (kg/ha) & 387 & 479 & 550 & 376 & 433 & 500 & $<0.001$ & $<0.001$ & 0.02 \\
\hline Fat $(\mathrm{kg} / \mathrm{ha})$ & 514 & 626 & 708 & 460 & 547 & 599 & $<0.001$ & $<0.001$ & 0.03 \\
\hline Milk (L/ha) & 13,406 & 16,146 & 18,136 & 12,363 & 14,541 & 16,100 & $<0.001$ & $<0.001$ & 0.07 \\
\hline
\end{tabular}

${ }^{1} \mathrm{GM}=$ genetic merit; $\mathrm{C}=$ level of concentrates; $\mathrm{GM} \times \mathrm{C}=$ interaction.

\section{Statistical Analysis}

Production Data-Individual Cow. A mixed linear model was developed with the following predictors: Concentrate: low C, medium C, and high C;

Season: time of calving (autumn or spring);

Year (time): year of observation (1995 to 1999);

Genetic merit: expressed as ABV units (continuous predictor).

This model proposes a quadratic relationship between yield and ABV. The relationship was allowed to vary according to concentrate, season, and year. The latter accounts for the potential cumulative effect of applying the same treatment over 5 yr [i.e., a quantitative fixed effect of time (Hansen et al., 2000)].

In addition, the model also included effects due to each animal and random deviation due to environmental conditions that are assumed to vary randomly from year to year (effect of year; Hansen et al. 2000) along with interactions between years and the fixed terms described previously. These terms were considered to be random effects (i.e., sources of variation in the data that are not of direct interest but included to obtain a fair estimate of experimental error). For example, standard error of predicted means will include estimates of random variation as well as variation due to the repeat observations on individual animals (autocorrelation) and variation due to year of observation (seasonality).

Significance testing of the random effects was carried out by conducting likelihood ratio tests on the contribution of each term to the log-likelihood of the model. Random effects which did not significantly enhance the model were deleted $(P>0.05)$.

The fixed terms were examined by conducting $F$-ratio test. When the test indicated that a term did not account for a significant degree of variation in the data $(P>$ $0.05)$, that term was also dropped from the model.

Production Data-Farmlets. The effects of genetic merit, concentrate level, and the interaction of genetic merit and level of concentrate (expressed on a per hectare basis) were analyzed by ANOVA using a factorial model with years as replicates. Significance was declared when $P<0.05$.

\section{RESULTS}

\section{Production}

Milk, fat, and protein per cow and per hectare, as well as milk composition, are shown in Table 2 . The production averages were all significantly different $(P<$ 0.05 ) between genetic merit and among level of feeding groups (with the exception of fat content) within genetic merit. The interaction between genetic merit $\times$ feeding level was significant $(P<0.05)$ for protein content, protein yield/cow and protein and fat yield/ha (Table 2 ).

\section{Comparison of Predicted ABV for Production and Actual Production}

On a farmlet basis, the average ABV for fat plus protein yield per cow, over the 5 yr of the study, was 49.1 and $2.3 \mathrm{~kg}$ for the HGM and LGM herds, respectively. This gave an ABV difference between genetic merit groups of $46.8 \mathrm{~kg}$ fat plus protein yield per cow (see Table 3).

On average, the HGM cows produced $28 \mathrm{~kg}$ more fat and $14 \mathrm{~kg}$ more protein per cow per lactation than the LGM cows, and this was similar to their predicted ABV differences of $28.9 \mathrm{~kg}$ of fat and $17.9 \mathrm{~kg}$ of protein per cow (see Table 3). However, the differences between genetic merit groups declined as the level of concentrate was reduced. This was particularly marked for protein yield where the difference fell from $16 \mathrm{~kg} / \mathrm{cow}$ for the high $\mathrm{C}$ herds to $6 \mathrm{~kg} / \mathrm{cow}$ for the low $\mathrm{C}$ herds (see Table 3). 
Table 3. Differences between high and low genetic merit groups in Australian Breeding Value (ABV) and actual production for fat plus protein yield for each level of concentrate (C)

\begin{tabular}{|c|c|c|c|c|}
\hline \multirow{2}{*}{$\begin{array}{l}\text { Milk component } \\
\text { (kg/cow per lactation) }\end{array}$} & \multirow{2}{*}{$\begin{array}{l}\text { Differences in ABV } \\
\text { between HGM } \\
\text { and LGM groups }\end{array}$} & \multicolumn{3}{|c|}{$\begin{array}{c}\text { Differences in actual production } \\
\text { between HGM and LGM } \\
\text { groups }\end{array}$} \\
\hline & & Low C & Medium C & High C \\
\hline Fat plus protein & 46.8 & 27 & 48 & 51 \\
\hline Fat & 28.9 & 21 & 28 & 35 \\
\hline Protein & 17.9 & 6 & 20 & 16 \\
\hline
\end{tabular}

\section{Interaction Between Genetic Merit and Level of Feeding on Fat and Protein Yield}

The interaction between genetic merit and level of feeding was more clearly demonstrated in the analysis of individual cows' data for milk, protein, and fat yield against their respective production ABV (Figures 1, 2, and 3).

The analysis of the data showed a highly significant $(P<0.001)$ effect of level of concentrates fed and ABV. The quadratic term for $\mathrm{ABV}$ and its interaction between $\mathrm{ABV}$ and level of concentrates were also significant $(P$
$<0.05)$. Significant random variation due to animals and years were also detected.

With the exception of fat yield (Figure 3), all relationships were quadratic but relatively flat for the low $\mathrm{C}$ cows with the slope increasing for the medium $\mathrm{C}$ cows and being steepest for the high $\mathrm{C}$ cows (Figures 1 and 3 ). However, even at the highest level of concentrate input (high C: $1.71 \mathrm{t} / \mathrm{cow}$ per lactation) the curve still flattened at the highest ABV values $(>600 \mathrm{~L}$ of milk and $>20 \mathrm{~kg}$ of protein), indicating that this level of feeding was still limited to $6,800 \mathrm{~L}$ of milk/cow per lactation at current management level.

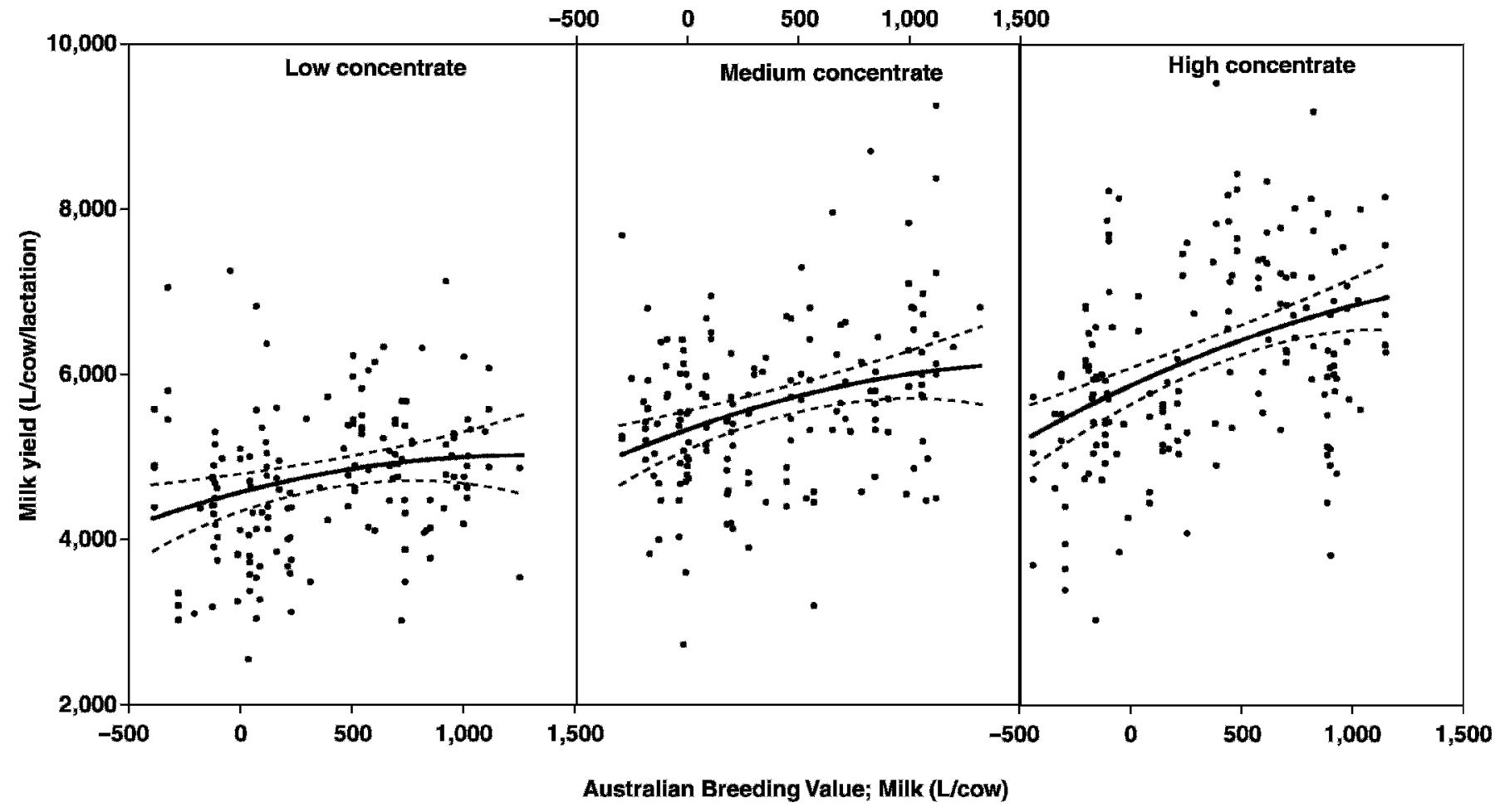

Figure 1. The predicted relationships between milk yield (L/cow) and Australian breeding value [ABV; milk yield (L)] for the third lactation. Observations ( have been adjusted for lactations 1,2, and 4 to 8 as well as the year's effects: Dashed lines enclose twice the standard errors of predictions. Low concentrate $(\mathrm{C})$ milk yield $(\mathrm{L} / \mathrm{cow})=4,564 \pm 95(P<0.001)+0.0445 \pm 0.37 \mathrm{ABV}$ milk yield +0.00005 $\pm 0.00042 \mathrm{ABV}$ milk yield ${ }^{2}$. Medium $\mathrm{C}$ milk yield $(\mathrm{L} / \mathrm{cow})=5,345 \pm 96(P<0.001)+0.17 \pm 0.45 \mathrm{ABV}$ milk yield $+0.00093 \pm 0.00045 \mathrm{ABV}$ milk yield ${ }^{2}$. High $\mathrm{C}$ milk yield $(\mathrm{L} / \mathrm{cow})=5,989 \pm 121(P<0.001)+2.2 \pm 0.42 \mathrm{ABV}$ milk yield $(P<0.001)+0.0017 \pm 0.0005 \mathrm{ABV}$ milk yield ${ }^{2}$. 


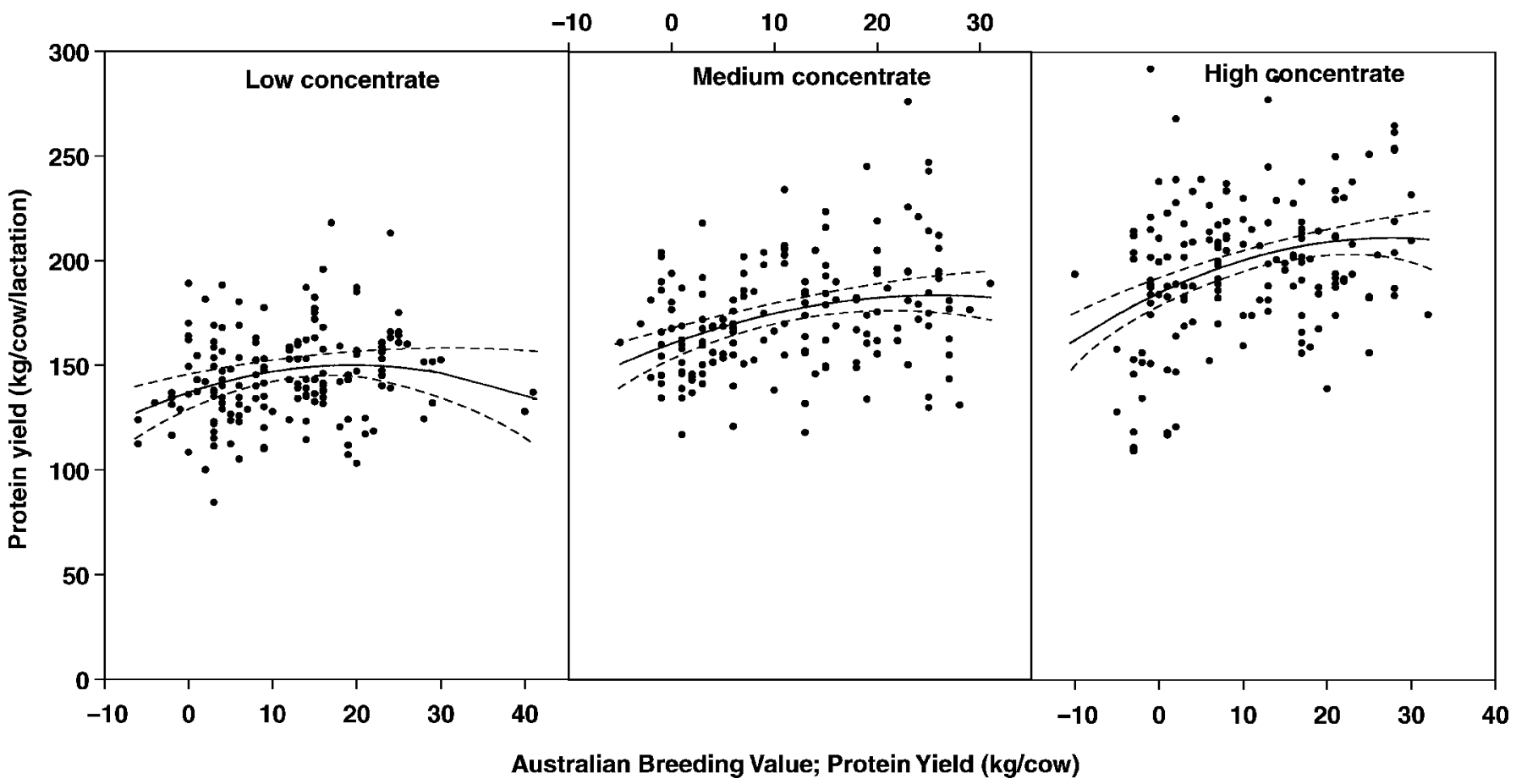

Figure 2. The predicted relationships between protein yield (kg/cow) and Australian breeding value [ABV; protein yield (kg)] for the third lactation. Observations $(-)$ have been adjusted for lactations 1, 2, and 4 to 8 as well as the year's effects: Dashed lines enclose twice the standard errors of predictions. Low concentrate $(C)$ protein yield $(\mathrm{kg} / \mathrm{cow})=138 \pm 3.4(P<0.001)+1.13 \pm 0.51 \mathrm{ABV}$ protein yield $(P<$ $0.03)-0.013 \pm 0.023 \mathrm{ABV}$ protein yield ${ }^{2}$. Medium $\mathrm{C}$ protein yield $(\mathrm{kg} / \mathrm{cow})=163 \pm 3.4(P<0.001)+1.2 \pm 0.6 \mathrm{ABV}$ protein yield $(P<0.05)$ $-0.013 \pm 0.023 \mathrm{ABV}$ protein yield ${ }^{2}$. High $\mathrm{C}$ protein yield $(\mathrm{kg} / \mathrm{cow})=184 \pm 4.0(P<0.001)+2.26 \pm 0.69 \mathrm{ABV}$ protein yield $(P<0.01)-0.05$ $\pm 0.028 \mathrm{ABV}$ protein yield $(P<0.001)^{2}$.

Protein yield followed a similar trend to milk yield but was more extreme with production being limited to about $210 \mathrm{~kg}$ of protein/cow per lactation (Figure 2). In contrast, fat yield increased linearly as ABV (fat yield, kg) increased, although the slope was also the steepest for the high $\mathrm{C}$ cows (Figure 3).

\section{Estimated Pasture Intake}

Table 4 provides a comparison of estimated intakes based on $\mathrm{ME}$ requirements for production and maintenance and on the ME density of feeds fed to the cows. The intakes were the average estimates for period 1 (predominantly ryegrass pasture) and period 2 (predominantly kikuyu pasture) over the 5 yr of the study.

On average, HGM cows utilized $11 \%$ more pasture/ ha than LGM cows. However, for both genetic merit groups, pasture utilization increased by 25 to $29 \%$ for the low $\mathrm{C}$ cows in comparison with the high $\mathrm{C}$ cows.

Based on these calculations, substitution rate of pasture for concentrates (i.e., the reduction in pasture DMI per unit increase in concentrate DMI) was less than half the rate for HGM - medium C compared with the other groups.

\section{Milk Production from Pasture}

Table 5 shows the total milk production/ha coming from pasture and from concentrates. For both genetic merit groups, the amount of milk production/ha from pasture decreased, and the amount of milk production/ ha from concentrate increased as concentrate level increased. However, on average over all concentrate levels, HGM cows produced $18 \%$ more milk from pasture than LGM cows.

\section{Response to Feeding Concentrates}

The marginal response to feeding concentrates is shown in Table 6 and is calculated as the extra liters of milk or kilograms of fat or protein produced from the extra kilograms of concentrate fed to the medium $\mathrm{C}$ and high $\mathrm{C}$ herds, relative to the low $\mathrm{C}$ herds.

The responses shown in Table 6 are expressed in terms of concentrates as fed and with a mean DM content of $92 \%$, the best response for the HGM - medium $\mathrm{C}$ cows of $1.75 \mathrm{~L}$ of $\mathrm{milk} / \mathrm{kg}$ of concentrates equates to $1.90 \mathrm{~L}$ of milk/kg of DM concentrate fed. This compares with a theoretical value (SCA, 1990) of 2.51 to $2.59 \mathrm{~L}$ of milk/kg of DM concentrates fed. Table 6 clearly shows 


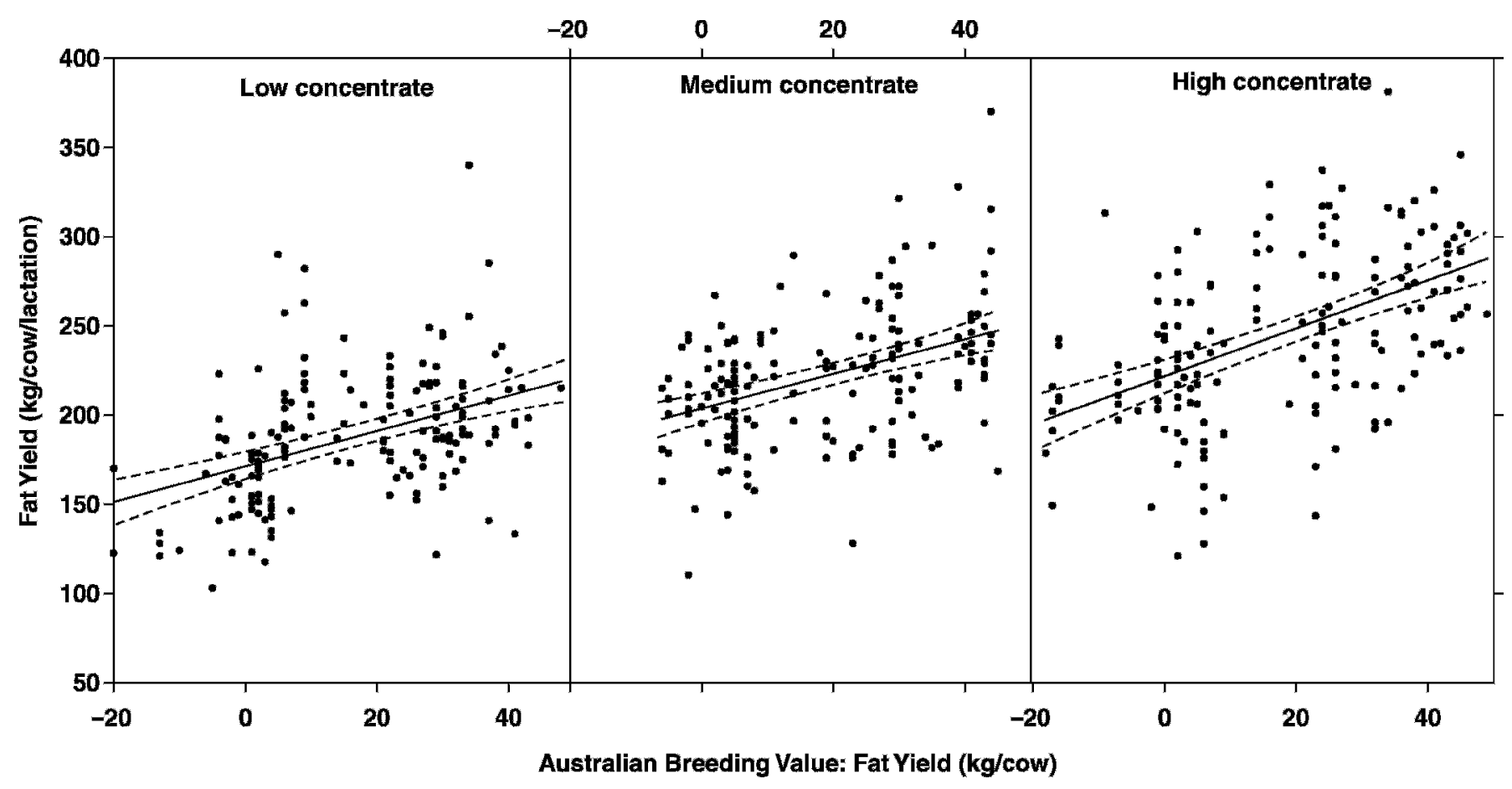

Figure 3. The predicted relationships between fat yield (kg/cow) and Australian breeding value [ABV; fat yield (kg)] for the third lactation. Observations (-) have been adjusted for lactations 1, 2, and 4 to 8 as well as the year's effects: Dashed lines enclose twice the standard errors of predictions. Low concentrate fat yield $(\mathrm{kg} / \mathrm{cow})=171 \pm 3.7(P<0.001)+0.99 \pm 0.17 \mathrm{ABV}$ fat yield $(P<0.001)$. Medium concentrate fat yield $(\mathrm{kg} / \mathrm{cow})=204 \pm 4.1(P<0.001)+0.97 \pm 0.17 \mathrm{ABV}$ fat yield $(P<0.001)$. High concentrate fat yield $(\mathrm{kg} / \mathrm{cow})=222 \pm 4.7(P<0.001)$ $+1.35 \pm 0.19 \mathrm{ABV}$ fat yield $(P<0.001)$.

Table 4. Estimated intake ( $\mathrm{t}$ of DM/ha) for the period when cows grazed predominantly kikuyu (January 1 to May 20) or ryegrass (May 21 to December 30) pastures, total intake, concentrates fed ( $\mathrm{t}$ of DM/ha per yr) and substitution rate ( $\mathrm{kg}$ of DM intake/kg of DM concentrate fed) of concentrate for pasture for cows fed medium (medium C) and high (high C) levels of concentrates relative to cows fed the lowest (low C) level of concentrates for each level of genetic merit (see Methods section regarding period 1 and 2)

\begin{tabular}{|c|c|c|c|c|c|c|}
\hline Item & \multicolumn{3}{|c|}{ High genetic merit } & \multicolumn{3}{|c|}{ Low genetic merit } \\
\hline Period 1: 1 Jan to 20 May (kikuyu) (t of DM/ha) & 5.5 & 5.3 & 4.3 & 4.7 & 4.8 & 4.0 \\
\hline Total pasture (t of DM/ha) & 10.0 & 9.7 & 8.0 & 9.3 & 8.4 & 7.2 \\
\hline Concentrate fed (t of DM/ha) & 0.77 & 2.03 & 4.78 & 0.73 & 2.07 & 4.45 \\
\hline Substitution rate ( $\mathrm{kg}$ of $\mathrm{DM}$ intake/kg of DM concentrate fed) & & 0.22 & 0.53 & & 0.65 & 0.54 \\
\hline Daily pasture intake of ME (MJ/cow per d) & 96.6 & 93.7 & 76.0 & 90.0 & 81.2 & 68.4 \\
\hline
\end{tabular}

Table 5. Milk production coming from pasture and from concentrate ( $\mathrm{L}$ of milk/ha per yr; production coming from concentrates was calculated from the ME of concentrates fed and the requirements of each herd for $\mathrm{ME}$ for milk based on the fat, protein, and lactose content of milk) ${ }^{1}$

\begin{tabular}{|c|c|c|c|c|c|c|}
\hline \multirow[b]{2}{*}{ Item } & \multicolumn{3}{|c|}{ High genetic merit } & \multicolumn{3}{|c|}{ Low genetic merit } \\
\hline & Low $\mathrm{C}$ & Medium C & High $\mathrm{C}$ & Low $\mathrm{C}$ & Medium C & High C \\
\hline Milk (L/ha·year) from pasture & 11,868 & 11,417 & 7,761 & 10,579 & 9,800 & 5,812 \\
\hline Milk (L/ha·year) from concentrate & 2,184 & 5,448 & 11,131 & 2,229 & 5,423 & 10,912 \\
\hline
\end{tabular}

${ }^{1}$ Note: Concentrate converted to DM basis by 0.92. Low C, medium C, and high $\mathrm{C}=$ lowest, medium, and highest levels of concentrates, respectively. 
Table 6. Mean $( \pm \mathrm{SE})$ marginal response to feeding concentrates $(\mathrm{C} ; \mathrm{L}$ of milk or $\mathrm{kg}$ of fat or protein/kg of concentrate as fed) of the medium $\mathrm{C}$ and high $\mathrm{C}$ herds relative to the low $\mathrm{C}$ herds

\begin{tabular}{lccccc}
\hline & \multicolumn{2}{c}{ High genetic merit } & & \multicolumn{2}{c}{ Low genetic merit } \\
\cline { 2 - 3 } \cline { 6 - 6 } Component & Medium C & High C & & Medium C & High C \\
\hline Milk (L/kg of C) & $1.75 \pm 0.30$ & $1.10 \pm 0.12$ & & $1.47 \pm 0.29$ & $0.92 \pm 0.15$ \\
Fat (kg/kg of C) & $0.055 \pm 0.014$ & $0.045 \pm 0.004$ & & $0.044 \pm 0.01$ & $0.035 \pm 0.01$ \\
Protein (kg/kg of C) & $0.060 \pm 0.007$ & $0.038 \pm 0.003$ & & $0.042 \pm 0.01$ & $0.031 \pm 0.004$ \\
\hline
\end{tabular}

the decline in response as the level of concentrates is increased, particularly for protein yield, and the higher response for the HGM compared with LGM cows.

\section{Effect of Increasing ABV on Fertility}

In the present study, the number of cows submitted (i.e., detected on heat and inseminated) in the first 24 $\mathrm{d}$ of the mating period was similar for all LGM cows (77, 74, and $77 \%$ for low $\mathrm{C}$, medium $\mathrm{C}$, and high $\mathrm{C}$, respectively), but decreased significantly for HGM cows as concentrate level decreased $(74,69$, and $49 \%$ for high $\mathrm{C}$, medium $\mathrm{C}$, and low $\mathrm{C}$ cows, respectively). This interaction between genetic merit and level of feeding was also significant for pregnancy rates at $24 \mathrm{~d}$ and 6 wk of mating, with the proportion of HGM low $\mathrm{C}$ cows pregnant after 6 wk of mating being 55\% lower than that of the best performing herd (LGM medium C, Fulkerson et al., 2001). After the average 9 wk of mating only the main effect of genetic merit was significant, with pregnancy rate of LGM cows (ABV for fat plus protein $=+2.3 \mathrm{~kg})$ and HGM cows $(+49.1 \mathrm{~kg})$ being 73 and $60 \%$, respectively (Fulkerson et al., 2001). The pregnancy rate decreased linearly as ABV for fat plus protein increased from -11 to $+70 \mathrm{~kg}\{[\mathrm{y}=9-0.21 \times$ $\left.\mathrm{ABV}(\mathrm{kg}) ; \mathrm{r}^{2}=0.75 ; P<0.01\right]$, Figure 4$\}$. This is equivalent to a decline of over 2 percentage units in pregnancy rate for every $10 \mathrm{~kg}$ increase in $\mathrm{ABV}$ for fat plus protein.

\section{DISCUSSION}

The results of the present study indicate a significant genotype $\times$ environment (primarily level of feeding) interaction on both reproduction (in this publication and previously published; Fulkerson et al., 2001) and production. This study was a 5-yr comparison using a closed farmlet system design and, as such, the response includes the cumulative effects on body condition, body size, reproductive performance, and pasture status. The results indicate that the HGM - low C (predominantly pasture fed) cows produced only $27 \mathrm{~kg}$ more fat plus protein/cow per lactation than the LGM - low C cows compared with 48 and $51 \mathrm{~kg}$ for the medium $\mathrm{C}$ and high $\mathrm{C}$ cows, respectively, when their predicted $\mathrm{ABV}$ difference was $46.8 \mathrm{~kg}$. Most of this was due to a lower difference in protein yield of $6 \mathrm{~kg}$ (or 34\%); this compares to a predicted ABV difference of $17.9 \mathrm{~kg}$. This effect on protein yield was reflected in a lower protein content of $2.89 \%$ for the HGM - low C cows compared with $3.03 \%$ for the mean of the remaining cows, and presumably reflects the greater degree of negative energy balance experienced in early lactation by this group (Clark, 2006).

Australian breeding values are calculated by comparing the production of cows in the same herd, and it is usually assumed that the high-yielding cows are eating more than the low-yielding cows. When HGM cows are run as a herd one might expect that they cannot all increase their intake and so the gain in production will be less than the difference in ABV. Surprisingly, in medium $\mathrm{C}$ and high $\mathrm{C}$ herds, the increase in yield approximately matches the increase in $\mathrm{ABV}$, presumably because the HGM cows can harvest more from the pasture than the LGM cows.

Notwithstanding the underfeeding of the HGM - low C cows, they still produced 4,953 L of milk/cow per

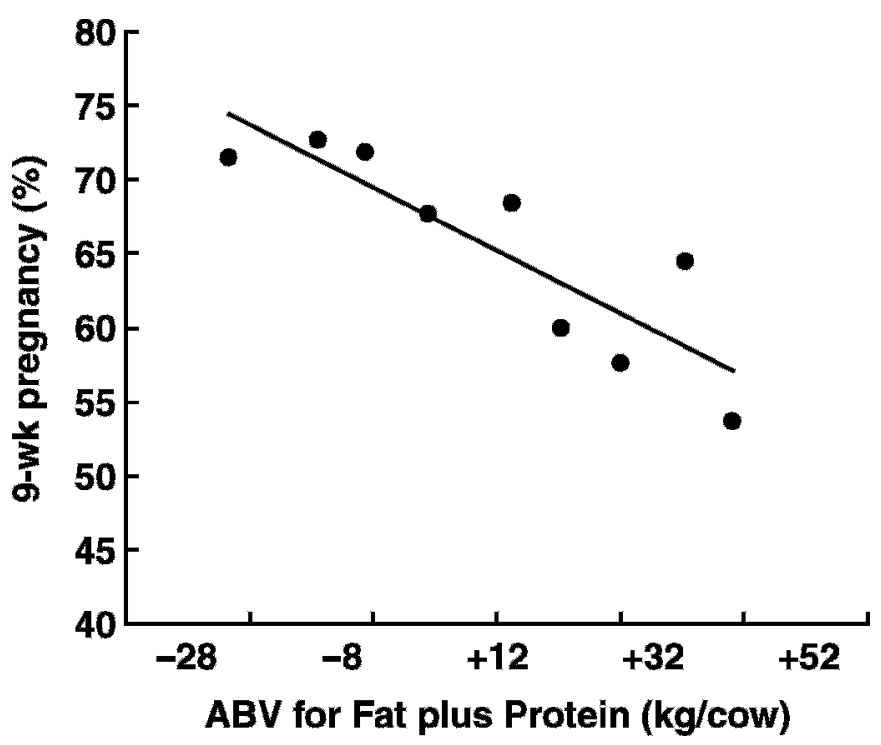

Figure 4. The relationship between Australian breeding value (ABV) for fat plus protein and 9-wk pregnancy rate in the present study. Mean value for $10 \mathrm{~kg} / \mathrm{cow}$ categories between $>-65$ to $15-25$ $\mathrm{kg}$ related to year 2000 base. [Pregnancy rate $(\%)=61( \pm 1.5)-0.21$ $( \pm 0.04) \times \mathrm{ABV}\left(\mathrm{kg}\right.$ of fat plus protein); $\left.\mathrm{R}^{2}=0.75 ; P<0.01\right]$. 
lactation which was just above the average for the region of 4,700 L of milk/cow per lactation. However, the industry standard for ABV in Australia in 1998 was 19 $\mathrm{kg}$ of fat plus protein, whereas the mean ABV of the HGM cows was $53 \mathrm{~kg}$ of fat plus protein, and it was obvious that these cows were prepared to mobilize more body reserves to meet the shortfall in intake. This is reflected in the lower body condition score (4.56 vs. 4.93) for the HGM and LGM cows, respectively (data not shown). The lower condition score of HGM cows is in line with other studies where cows were confined indoors (Veerkamp and Brotherstone, 1997) or managed under pasture-based systems (Buckley et al., 2000; Horan et al., 2005). In this regard, Veerkamp et al. (2001) went on to show that increasing the proportion of Holstein-Friesian genes (North American) from 50 to $100 \%$ decreased condition score by 1 unit (scale of 1 to 9 ). In our study, there was a $40 \%$ unit ( 21 vs. $61 \%$ for LGM and HGM cows, respectively) difference in North American genes, and this equates to an average body condition score difference of 0.42 (converted to scale 1 to 9). Therefore, a 50\% increase in HolsteinFriesian genes would be equivalent to a 0.53 condition score difference.

The HGM cows in this study are genetically similar to cows in the USA that produce over $10,000 \mathrm{~L}$ of milk/ cow per lactation under intensive management conditions. The production of the cows in this study was likely restricted by cow size, condition at calving and level of feeding postcalving, as is normal under a pasture-based system. In this regard, dry cows were run on their respective farmlets for most of the time and although they all recovered body condition, the score at calving reflected level of feeding during lactation and was below values normally found in northern hemisphere cows.

Although heifers were targeted to calve at $550 \mathrm{~kg}$ of live weight, as recommended by Radostits and Blood (1985), many of the original animals allocated to this study were smaller at first calving, and this is reflected in the relatively low average of $523 \mathrm{~kg}$ (converted to a condition score of 5), or a mature live weight of $537 \mathrm{~kg}$, for the HGM - high C cows.

Studies on the interaction between genetic merit for production and environment (feeding) have used controlled experiments or large sets of herd recording data, and the results have been variable. In the controlled studies, conflicting results have been associated with length of study, the lack of difference in genetic merit, the level of feeding, or a combination of these.

\section{Controlled Experiments}

In the earlier work at Langhill, Scotland, Veerkamp et al. (1995) found no significant interaction between genetic merit and level of feeding. The feeding level treatments related to change in the ratio of concentrate to roughage ( $45 \%$ concentrate; $2.5 \mathrm{t} / \mathrm{cow}$ per lactation vs. $20 \%$ concentrate; $1.0 \mathrm{t} / \mathrm{cow}$ per lactation) input to control [pedigree index (PI) of $4.3 \mathrm{~kg}$ of fat plus protein] or selected (for milk production; PI of $18.8 \mathrm{~kg}$ of fat plus protein) groups of cows. Although this was also a longterm study (over $5 \mathrm{yr}$ ), the differences in level of feeding were restricted to the concentrate:roughage ratio, fed ad libitum with roughage, and the genetic merit difference was small (PI difference of $14.5 \mathrm{~kg}$ ).

Despite the lack of significant effects, Veerkamp et al. (1995) did find that the regression coefficient of milk yield, protein yield, and protein percentage on PI for fat plus protein yield was different between low and high levels of concentrate. Veerkamp et al. (1995) concluded that "staying with solely selecting for production, particularly on low input diets increases yield (as a result of continual selection for production under high input diets), may be limited by the extent of tissue mobilization: under these circumstances health and fertility problems might be the first indicators of such a limited approach".

In the initial Irish study conducted from 1995 to 1997, Buckley et al. (2000) found no significant interaction between genetic merit and environment under a predominantly grazed pasture situation when feeding high (1.12 t/cow per lactation) or low (0.672 t/cow per lactation) levels of concentrate. The predicted difference (PD) between HGM and LGM groups was $15 \mathrm{~kg}$ of fat plus protein with the LGM cows being typical of the national herd at that time. These differences in genetic merit and level of feeding were relatively smaller than in the present study and in recognition of this shortcoming, the Irish group (Kennedy et al., 2003) went on to study levels of feeding similar to ours, viz. 376, 810, and $1,540 \mathrm{~kg}$ of concentrate/cow per lactation. From the results of this study, they also concluded that "The significant genotype $\times$ feeding system interaction in the regression analysis ... suggest that cows of very high genetic merit may have expression of their milk potential compromised by inadequate concentrate feeding in a grass-based system." This was also the conclusion of this study.

Horan et al. (2005) compared 3 genetically different groups (North American; high production but also selected for survival; and New Zealand strain) by 3 levels of feeding (pasture; high concentrate; high stocking rate) with the predicted transmitting ability difference between North American animals and the group selected for survival being about $15 \mathrm{~kg}$ of fat plus protein. Again there was a significant genotype $\times$ feeding interaction for fat and protein yield. 
In New Zealand, Kolver et al. (2002) also reported a significant genotype by feeding interaction when comparing North American and New Zealand HolsteinFriesians on an all pasture or TMR feeding system. As the genetic merit value of the 2 groups was similar, the authors argue for a strain rather than a genetic merit influence. This could be true, but certainly in Australia, strain (North American) is synonymous with milk production. The authors also questioned the suitability of the North American genotype for pasture-based systems in view of their overreliance on mobilization of body reserves leading to very poor fertility. Low reproductive performance threatens the opportunity to seasonally calve, a determinant of profitability in pasturebased systems of farming.

\section{The Use of Herd Recording Data}

A number of studies have used herd recording data to look at the interaction between genotype and environment. However, although it has the power of sample size it can only look at production/cow and not the whole farm impact.

The interaction between level of feeding and genetic merit is seen in differences in correlation coefficients and in scaling when the ranking of bulls on breeding values remains the same between countries but the differences between bulls varies between countries. This was the case in a study in Ireland undertaken by Cromie et al. (1999) where the data of 20,510 cows on farms feeding high or low levels of concentrate (1.58 and $0.54 \mathrm{t} / \mathrm{cow}$ per lactation, respectively) were analyzed. They compared the EBV of cows in the high concentrate herds with US EBV (average concentrate fed was $3 \mathrm{t} /$ cow per lactation) and found that when the US EBV were $100 \mathrm{~kg}$ of milk, the EBV of the high concentrate herds were $66 \mathrm{~kg}$-a scaling of 0.66 (i.e., a bull with a proof of $100 \mathrm{~kg}$ in the United States could only be expected to provide a benefit of $66 \mathrm{~kg}$ in high concentrate herds in Ireland). The scaling is close to the adjustments made by Interbull to the proofs of US bulls used in Ireland. However, the production from cows in low $\mathrm{C}$ herds gave proofs of $37 \mathrm{~kg}$ or a scaling effect of 0.37 . The amount of concentrates fed/cow and the scaling effects are very similar to that found in our study. In addition, Carabano et al. (1989) found that the correlation between sire proofs of US sires in Spain, with relatively low production $(170 \mathrm{~kg}$ of fat/cow per lactation), and in the United States (280 kg of fat/cow per lactation) was very low.

Weigel et al. (2001) used cluster analysis to evaluate cows from different countries (i.e., different environments) using the Interbull multitrait analysis. They found very high genetic correlations for production be- tween countries with the same feeding management; for example, genetic correlation among Australia, Ireland, and New Zealand (all pasture-based systems) were 0.96 with the correlations the same among Belgium, Canada, Italy, the Netherlands, and the United States (intensive feeding systems). Correlations between these 2 groups dropped to 0.80 to 0.90 . However, they felt that the fall in genetic correlation when comparing between different feeding systems and within feeding systems was not enough to warrant separate selection. Following up from this work, clustering by different environments was proposed as a model to predict estimated breeding values for dairy sires based on the production environment in which the sires' progeny would perform independently of country or location (Zwald et al., 2003a,b).

In 2002, Kolmodin et al. (2002) used predicted reaction norms for young bulls in Nordic red breeds from 927,929 herd recording records. They regressed phenotype values for production on herd environment and used protein production and days open to define herd environment. They also found a significant interaction between genotype and environment (both scaling effects and reranking of sires). The authors state that "for low performance herds, there would be some benefit in ranking sires according to the herd in which they will be used." Hayes et al. (2003) also reports a genetic correlation of 0.78 between protein yield where cows averaged $0.54 \mathrm{~kg}$ of protein/d and herds averaging 1.1 $\mathrm{kg} / \mathrm{d}$. Similarly, Boettcher et al. (2003) found a significant scaling effect when comparing proofs of bulls taken under grazing or confinement dairies in Canada. However, as $\mathrm{G} \times \mathrm{E}$ for milk yield was small with a genetic correlation $>0.90$, it was probably not worth selecting for different environments.

The impact of inflow of North American HolsteinFriesian genes on cows' performance is very clearly illustrated by an Irish study of 5,880 cows over a period of $11 \mathrm{yr}$ (Evans et al., 2004). This study shows a decrease in conception rate to first service from 55 to $44 \%$ in association with an increase in the proportion of North American genes of cows from 8 to $63 \%$.

Taken together, the results of experiments, analysis of herd recording data and results from the current study indicate that the biggest reranking, within temperate regions, occurs between environments with high production and high concentrate feeding and environments with only pasture feeding and low production. For instance, Interbull estimates the genetic correlation between milk yield in the United States and New Zealand to be 0.75 (Interbull, 2007).

\section{Response to Feeding Concentrates}

The results of the present study provide useful information on the long term regarding whole-farm re- 


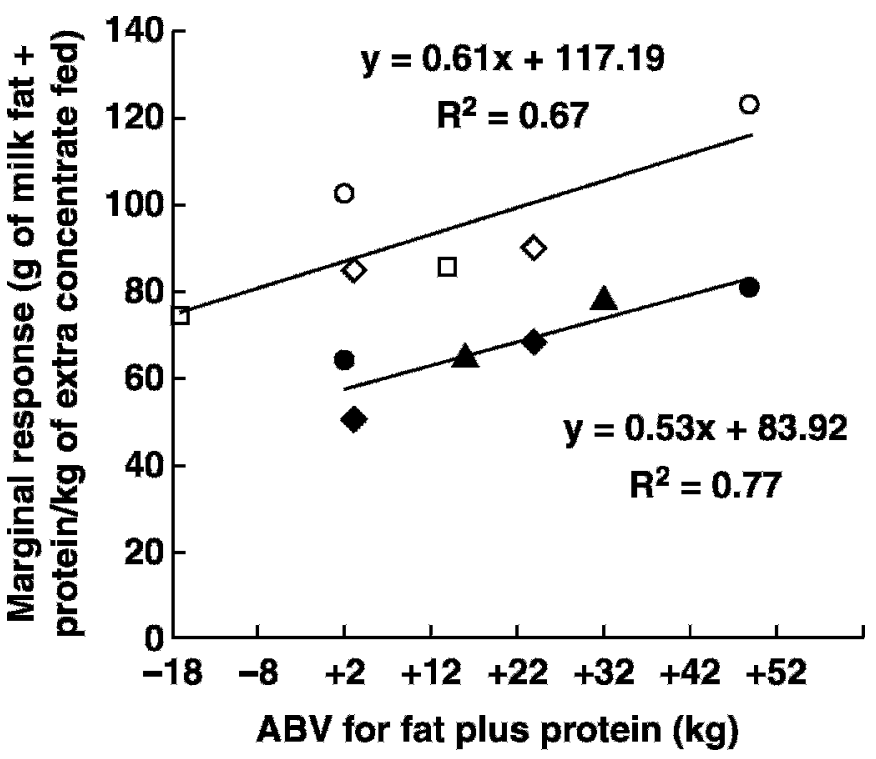

Figure 5. Effect of Australian breeding value (ABV) for fat plus protein on the marginal response to concentrate ( $\mathrm{g}$ of fat plus protein/ $\mathrm{kg}$ of extra concentrate fed) for cows in the medium (open symbols) or high (solid symbols) concentrate group. Data from the present study $(\bigcirc, \bullet)$, Buckley et al. (2000) $(\square)$, Kennedy et al. (2003) $(\diamond, \diamond)$, and Horan et al. (2005) ( $\mathbf{\Delta})$.

sponses to feeding concentrates to Holstein-Friesian cows grazing pasture and of different genetic merit. The production response to concentrates declined as the amount of concentrate increased from 0.84 to 1.71 $t$ of concentrate/cow per lactation but was higher for the HGM than for the LGM cows.

The response of the HGM - medium $\mathrm{C}$ cows was very high at $1.91 \mathrm{~L}$ of milk/kg of DM concentrate and compares with a theoretical maximum of $2.46 \mathrm{~L}$ of milk/ $\mathrm{kg}$ of DM (SCA, 1990) for milk of that composition. In comparison, and as expected, the lowest value of 1.00 $\mathrm{L}$ of milk/kg of DM concentrate belonged to the LGM high $\mathrm{C}$ cows.

The marginal response to feeding concentrates to pasture-fed Holstein-Friesian cows which differ in genetic merit has also been measured in 3 Irish studies (Buckley et al., 2000; Kennedy et al., 2003; Horan et al., 2005). To compare their results with the results from the current study, the Irish PD for fat plus protein were converted to $\mathrm{ABV}$ for fat plus protein using the appropriate Interbull conversion coefficients [0.77 and 0.75 for fat and protein, respectively (Interbull, 2006)]. The ABV for fat plus protein were then regressed on the marginal response to concentrates fed at a medium (2.7 to $3.5 \mathrm{~kg} / \mathrm{cow}$ per d) and high (4.9 to $5.7 \mathrm{~kg} / \mathrm{cow}$ per d) level, excluding the marginal response of the LGM cows fed at medium and high concentrate levels (Figure 5).
Thus, combining data of 4 studies including those from the current study, Figure 5 clearly shows that i) the marginal response to concentrate increased as ABV for fat plus protein $(\mathrm{kg})$ increased, independently of the level of concentrate fed; and ii) the marginal response to concentrate was higher when cows were fed medium rather than higher levels of concentrate, independently of their ABV.

The increased marginal response to concentrate as $\mathrm{ABV}$ increases is likely due to the greater intake potential of high genetic merit cows. In the current study, HGM cows ate $11 \%$ more DM than LGM cows (see Table 4). Buckley et al. (2000) found marginal responses to feeding concentrates to LGM (PD $=230 \mathrm{~kg}$ of milk) and HGM (PD = $4 \mathrm{~kg}$ milk) cows of 1.12 and $0.92 \mathrm{~kg}$ of milk/ $\mathrm{kg}$ of DM concentrate fed. The comparable figures for the current study were 1.56 and $1.29 \mathrm{~kg}$ of milk/ $\mathrm{kg}$ of DM concentrate fed. Buckley et al. (2000) also reported a substitution rate of 0.40 and $0.25 \mathrm{~kg}$ of DM grass/ $\mathrm{kg}$ of DM concentrate fed for LGM and HGM cows, respectively. In the current study, substitution rates of 0.60 and $0.38 \mathrm{~kg}$ of DM pasture $/ \mathrm{kg}$ of DM concentrate were obtained respectively for LGM and HGM cows, which are similar to those obtained by Kennedy et al. (2003) of 0.57 and $0.36 \mathrm{~kg}$ of DM pasture $/ \mathrm{kg}$ of DM concentrate. This indicates the greater intake potential of higher genetic merit cows.

On the other hand, the negative relationship between high energy dense concentrate input when fed twice-aday at milking and production responses is in line with results of Walker et al. (2001). Expressing their results as increased milk yield ( $\mathrm{L} / \mathrm{kg}$ of DM incremental increase in supplement intake), the efficiency of use of concentrate rose from $1.1 \mathrm{~L} / \mathrm{kg}$ of concentrate at $3 \mathrm{~kg}$ concentrate to 1.3 at $5 \mathrm{~kg}$ of concentrate then fell to 0.8 and $0.4 \mathrm{~L} / \mathrm{kg}$ at 7 and $9 \mathrm{~kg}$ of concentrate, respectively. Walker et al. (2001) also summarized the marginal responses to grain feeding for other Australian studies and found a similar trend (see Figure 6). In all cases, the production response to feeding up to $4 \mathrm{~kg}$ of concentrate/ cow day was high but the response after that declined.

The very high response to concentrate input in the current study was due to a number of factors:

1. Cows were of high genetic merit for fat plus protein production with a mean $\mathrm{ABV}$ of $54 \mathrm{~kg}$ of fat plus protein.

2. The stocking rate was equivalent to about 3.2 cows/ha compared with a regional average of less than 1 cow/ha.

3. The response of the HGM - medium C cows was high for the first $2.9 \mathrm{~kg}$ of concentrate/cow per $\mathrm{d}$ and also declined as we fed $5.8 \mathrm{~kg} / \mathrm{cow}$. 


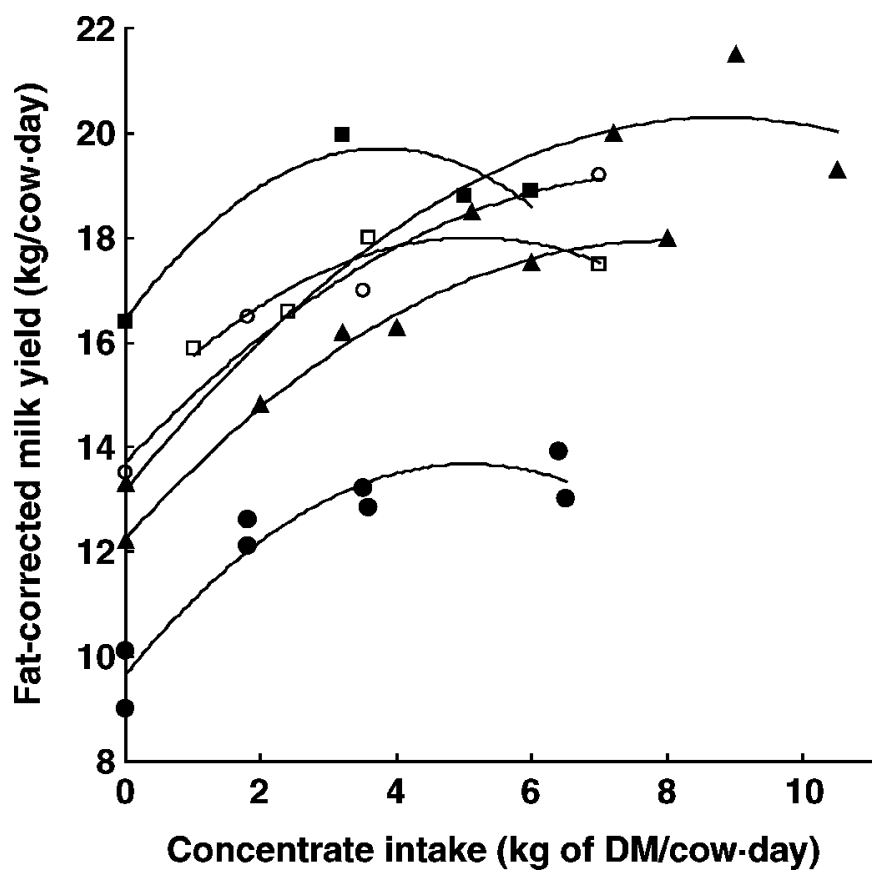

Figure 6. Relationships between fat-corrected milk production and intake of cereal grain-based concentrates from controlled experiments in Australia [curves represent a controlled experiment or treatments within an experiment; adapted from Walker et al. (2001; reproduced with permission)].

4. Concentrates (and particularly maize silage) were strategically fed in relation to pasture availability. Thus, most concentrate was fed in autumn to help fill the large feed gap at that time of year and to balance nutrients deficient in maize silage (protein) and pasture (rapid fermentable carbohydrates relative to protein). In spring, as little as $1 \mathrm{~kg} / \mathrm{cow}$ per $\mathrm{d}$ was fed in a situation where ample high quality ryegrass was available.

\section{CONCLUSIONS}

In summary, a significant interaction was found between genetic merit for milk production and feeding system (viz. concentrate level) in a predominantly grazing (pasture-based) system, for milk and reproductive traits. Thus, the cows' response (in terms of milk, fat, and protein production) to concentrate level increased as genetic merit (ABV) increased, whereas reproductive performance decreased linearly as ABV increased.

This conclusion is supported by analyses of both individual cow and whole farm system data. At the individual cow level, the quadratic nature of the milk and protein production in response to increasing level of genetic merit indicates that the full phenotypic expression of increased genetic merit cows is compromised even at the maximum level of concentrate used in this study. At the whole system level, results show a decreased reproductive efficiency as genetic merit increased, associated with a drop in cows body condition (and an increase in negative energy balance) for the high genetic merit cows.

These results suggest that, if progeny test systems of equal size were available in grass based systems and high concentrate systems, farmers would benefit from selecting bulls' progeny tested in a similar environment as their own. On the contrary, if the selection for milk production continues in Australia in the same manner, farmers will have to modify their production system accordingly by feeding higher levels of concentrates to cows (to reach potential production) or abandon seasonal calving due to poorer reproductive performance, or both. Both would result in an increased cost of milk production and a walk away from predominantly grazing, pasture-based system, which has been, and to date is, the largest competitive advantage of the Australian dairy industry.

\section{ACKNOWLEDGMENTS}

The authors wish to acknowledge the excellent technical support provided by Richard Bryant, Bill Davies, and Steve Morris, New South Wales, Department of Primary Industries; Steve Morris undertook statistical analysis of individual cow data. Financial support was provided by Dairy Australia.

\section{REFERENCES}

Boettcher, P. J., J. Fatehi, and M. M. Schutz. 2003. Genotype $\times$ environment interactions in conventional versus pasture-based dairies in Canada. J. Dairy Sci. 86:383-404.

Bonczeb, R. R., D. D. Richardson, E. D. Moore, R. H. Miller, J. R. Owen, H. H. Dowlen, and B. R. Bell. 1992. Correlated responses in reproduction accompanying selection for milk yield in Jerseys. J. Dairy Sci. 75:1154-1160.

Buckley, F., P. Dillon, M. Rath, and R. F. Veerkamp. 2000. The relationship between genetic merit for yield and liveweight, condition score and energy balance of Holstein-Friesian dairy cows on grass based systems of milk production. J. Dairy Sci. 83:18781886.

Carabano, M. J., L. D. Van Fleck, and G. R. Wiggans. 1989. Estimation of genetic parameters fro milk and fat yields of dairy cattle in Spain and the United States. J. Dairy Sci. 72:3013-3022.

Clark, C. E. F. 2006. Identifying indicators of energy balance for pasture based dairy cows in early lactation. $\mathrm{PhD}$ Thesis. University of Sydney, Australia.

Colman, D., Y. Zhuang, and J. R. Franks. 2004. UK milk production following the 2003 reform of the CAP. CAFRE Economics studies, The University of Manchester.

Cromie, A. R., D. Kelleher, and F. J. Gordon. 1999. The impact of dairying environment on the response to increases in genetic merit in dairy herds. [A review]. Agric. Res. Inst. Northern Ireland 72nd Annu. Rep. 1998-1999. 49-56.

Dairy Outlook. 2006. Dairy 2006: Situation and Outlook. Report to the Australian Dairy Industry. Dairy Outlook, June 2006. Dairy Australia, Melbourne, Australia. 
Dillon, P., D. P. Berry, R. D. Evans, F. Buckley, and N. Horan. 2006. Consequences of genetic selection for increased milk production in European seasonal pasture based systems of milk production. Livest. Sci. 99:141-158.

Earle, D. 1976. A guide to scoring dairy cow condition. J. Agric. Victoria 74:228-230.

Evans, R. D., P. Dillon, and L. Shalloo. 2004. An economic comparison of dual purpose and Holstein-Friesian cow breeds in a seasonal grass-based system under different milk production scenarios. Irish J. Agric. Food Res. 43:1-16.

Foote, R. H. 1978. Reproductive performance and problems in New York dairy herds. Cornell University, Agricultural Experimental Station. Search, Agriculture 8:1-10.

Fulkerson, W. J., and A. J. Dickens. 1985. Reproductive performance of autumn and spring calving dairy cows. Pages 188-190 in Proc. Dairy Prod. Conf. Combined Aust./NZ Soc. Anim. Prod. Meeting Albury/Wodonga. Clark and Matheson Ltd., Hamilton, New Zealand.

Fulkerson, W. J., and D. J. Donaghy. 2001. Plant soluble carbohydrate reserves and senescence-Key criteria for developing an effective grazing management system for ryegrass-based pastures, a review. Aust. J. Exp. Agric. 41:261-275.

Fulkerson, W. J., and P. Doyle. 2001. The Australia Dairy Industry. Vic. Dep. Nat. Res. and Environ., Victoria, Australia.

Fulkerson, W. J., K. Slack, D. W. Hennessy, and G. M. Hough. 1998. Nutrients in ryegrass (Lolium spp.), white clover (Trifolium repens) and kikuyu (Pennisetum clandestinum) pastures in relation to season and stage of regrowth in a subtropical environment. Aust. J. Exp. Agric. 38:227-240.

Fulkerson, W. J., J. Wilkins, R. C. Dobos, G. M. Hough, M. E. Goddard, and T. Davison. 2001. Reproductive performance in HolsteinFriesian cows in relation to genetic merit and level of feeding when grazing pasture. Anim. Sci. 73:397-406.

Grainger, C., C. W. Holmes, and Y. F. Moore. 1985. Performance of Friesian cows with high and low breeding indexes. 2. Energy and nitrogen balance experiments with lactating and pregnant, nonlactating cows. Anim. Prod. 40:389-400.

Hansen, E. M., K. Kristensen, and J. Djurhuus. 2000. Yield parameters as affected by introduction or discontinuation of catch crop use. Agron. J. 92:909-914.

Harrison, R. O., S. P. Ford, J. W. Young, A. J. Conley, and A. E. Freeman. 1990. Increased milk production versus reproductive and energy status of high producing dairy cows. J. Dairy Sci. 73:2749-2758.

Hayes, B., M. Carrick, P. Bowman, and M. E. Goddard. 2003. Genotype $\times$ environment interaction for milk production of daughters of Australian dairy sires from test-day records. J. Dairy Sci. 86:3736-3744

Holmes, C. W., and K. L. MacMillan. 1982. Nutritional management of the dairy herd grazing on pasture. Occasional Publication, New Zealand Society of Animal Production 8 (Dairy production from pasture), 244-274

Horan, B., P. Dillon, P. Faverdin, L. Delaby, F. Buckley, and M. Rath. 2005. The interaction of strain of Holstein-Friesian cows and pasture-based feed systems on milk yield, body weight, and body condition score. J. Dairy Sci. 88:1231-1243.

Interbull. 2006. Genetic evaluation. Production. http://www-interbull.slu.se/eval/framesida-prod.htm Accessed Feb. 22, 2007.

Interbull. 2007. Genetic evaluation. Production. http://www-interbul1.slu.se/eval/framesida-prod.htm Accessed Sep. 5, 2007.

Judd, T. G., N. A. Thomson, and D. A. McCallum. 1990. Pasture management and pasture species for improved dry matter production in south Taranaki. Proc. New Zealand Grassl. Assoc. 51:109-112.

Kellaway, R., and T. Harrington. 2004. Feeding concentrates, supplements for dairy cows. R. Kellaway and T. Harrington, ed. Landlinks Press, Collingwood, Australia.

Keller, D. S., and F. R. Allaire. 1989. Milk component yields versus concentrations as selection criteria to improve milk revenue. J. Dairy Sci. 72:3259-3263.
Kennedy, J., P. Dillon, L. Delaby, P. Faverdin, G. Stakelum, and M. Rath. 2003. Effect of genetic merit and concentrate supplementation on grass intake and milk production with Holstein-Friesian dairy cows. J. Dairy Sci. 86:610-621.

Kolmodin, R., E. Strandberg, P. Madsen, J. Jensen, and H. Jorjani. 2002. Genotype by environment interaction in Nordic dairy cattle studied using reaction norms. Acta Agric. Scand. 52:11-24.

Kolver, E. S., J. R. Roche, M. J. de Veth, P. L. Thorne, and A. R. Napper. 2002. Total mixed rations versus pasture diets: Evidence for a genotype $\times$ environment interaction in dairy cows. Proc. New Zealand Soc. Anim. Prod. 62:246-251.

Morton, J. M. 2003. The InCalf book for dairy farmers. Dairy Australia, Melbourne, Australia.

Northcote, K. H. 1974. A factual key for the recognition of Australian soils. Rellim Technical publication, Glenside, South Australia.

Radostits, O. M., and D. C. Blood. 1985. Herd Health: A Textbook of Health and Production Management of Agricultural Animals. W. B. Saunders, Philadelphia, PA.

Rauw, W. M., E. Kanis, E. N. Noordhuizen-Stassen, and F. J. Grommers. 1998. Undesirable side effects of selection for high production efficiency in farm animals (a review). Livest. Prod. Sci. 56:15-33.

Reeves, M., W. J. Fulkerson, and R. C. Kellaway. 1996. Forage quality of kikuyu (Pennisetum clandestinum), the effect of time of defoliation and nitrogen fertiliser application and in comparison with perennial ryegrass (Lolium perenne). Aust. J. Agric. Res. 47:1349-1359.

SCA (Standing Committee on Agriculture and Resource Management). 1990. Feeding standards for Australian livestock. Ruminants CSIRO publications, Australia.

USDA. 1964. Milk production. Statistical Reporting Service.

USDA. 2006. Milk production. National Agricultural Statistics Service (NASS)

van Vuuren, A. M. 1993. Digestion and nitrogen metabolism of grass fed dairy cows. Research Institute for Livestock, Feeding and Nutrition. PhD Thesis. Wageningen, the Netherlands.

Veerkamp, R. F., and S. Brotherstone. 1997. Genetic correlations between linear type traits, food intake, live weight and condition score in Holstein Friesian dairy cattle. Anim. Sci. 64:385-392.

Veerkamp, R. F., W. G. Hill, A. W. Stott, S. Brotherstone, and G. Simm. 1995. Selection for longevity and yield in dairy cows using transmitting abilities for type and yield. Anim. Sci. 61:189-197.

Veerkamp, R. F., E. P. C. Koenen, and G. DeYong. 2001. Genetic correlations amongst body condition score, yield and fertility in first parity cows estimated by random regression models. J. Dairy Sci. 84:2327-2335.

Walker, G. P., C. R. Stockdale, W. J. Wales, P. T. Doyle, and D. W. Dellow. 2001. Effect of level of grain supplementation on milk production responses of dairy cows in mid-late lactation when grazing irrigated pastures high in paspalum (Paspalum dilatatum Poir.). Aust. J. Exp. Agric. 41:1-11.

Weigel, K., R. Rekaya, N. R. Zwald, and W. F. Fikse. 2001. International genetic evaluation of dairy sires using a multiple-trait model with individual animal performance records. J. Dairy Sci. 84:2789-2795.

Yan, T., C. S. Mayne, T. W. J. Keady, and R. E. Agnew. 2006. Effects of dairy cows genotype with 2 planes of nutrition on energy partitioning between milk and body reserves. J. Dairy Sci. 89:10311042.

Zwald, N. R., K. A. Weigel, W. F. Fikse, and R. Rekaya. 2003a. Application of a Multiple-Trait Herd Cluster model for genetic evaluation of dairy sires from seventeen countries. J. Dairy Sci. 86:376-382.

Zwald, N. R., K. A. Weigel, W. F. Fikse, and R. Rekaya. 2003b. Identification of factors that cause genotype by environment interaction between herds of Holstein cattle in seventeen countries. J. Dairy Sci. 86:1009-1018. 